\title{
Reference Books of 1952-1953
}

Miss Winchell is reference librarian, Columbia University Libraries.

\section{Introduction}

A $S$ IN PREVIOUS ARTICLES in this series ${ }^{1}$ 1 this survey is based on notes written by members of the reference staff of the Columbia University Libraries. There has been some experimentation as to the form the listing should take-the first two numbers were survey articles followed by alphabetical lists, the third was an annotated bibliography, the entries being given in much the same form as is used in the Guide to Reference Books. 7 th ed. ${ }^{2}$ Some reference librarians have indicated a preference for this last as they believe it is easier to check and to use with the Guide. Therefore, this is the arrangement used.

Once again, as the purpose of the list is to present a selection of scholarly and foreign works of interest to university libraries, it is not necessarily well-balanced nor comprehensive. Code numbers (such as AI6) have been used to refer to titles in the Guide. ${ }^{2}$

\section{Bibliography}

Index bibliographicus: Directory of Current Periodical Abstracts and Bibliographies, Répertoire des revues courants de bibliographies analytiques et -signalét ques. Comp. by Theodore Besterman. Paris, UNESCO, I952- V.I-2 (In progress)

Ist ed., I925; 2nd ed., I93 I (AI6). This is the $3 \mathrm{rd}$ ed. completely revised.

v. I, Science and technology; v.2, Social sci-

${ }^{1}$ College and Research Libraries, 13: 30-36, 234-41, Jan, July 1952; 14:72-78, Jan. 1953.

. Guide to Reference Books. 7th ed. Chicago, ALA, 1951. ences, education, humanistic studies. List published bibliographies in book form and in periodicals. Arranged by the Universal Decimal Classification.

Malclès, L. N. Les sources du travail bibliographique. Genève, E. Droz; Lille, Giard, 1952. v.2 in 2 pts.

This is the second volume of this notable bibliographic manual, the first dealing with general bibliography was published in 1950 and noted previously. (College and Research Libraries 13:30, Jan. 1952). This second volume devoted to the humanities and the social sciences is not limited to bibliographies but includes dictionaries, encyclopedias, atlases, texts, periodicals, and other types of reference and source materials. There are also special sections on the language, literature and history of Slavic and Balkan countries and of the Near, Middle and Far East. A full index by author, subject and title completes the volume.

Volume three is to cover the natural sciences and medicines.

\section{Periodicals}

Dahl, Folke. A Bibliography of English Corantos and Periodical Newsbooks, I620-I642. London, Bibliographical Society, 1952. 283p. il.

This is an expansion of his earlier "Shorttitle catalogue of English corantos and newsbooks, I640-1642" which appeared in The Library in June 1938. Its aim is to "list and describe all corantos and newsbooks of foreign news in the English language printed during the period 1620-1642".

Detailed bibliographical descriptions are given with reference to sources and locations of copies. The corantos are arranged in chronological order under places of printing; the newsbooks are listed in chronogical order in their series. Introductions to sections and notes give changes of publisher, mode of printing, size, typographical features, identification of printers, variant copies, etc. There is no index. 
Türkiye makaleler bibliyografyasi. Bibliographie des articles parus dans les périodiques turcs. Istanbul, I952-

no.I, Mart I952- (Millî kütüphane bibliyografya enstitüsü yayimlarindan. Publications de l'Institut national turc de bibliographie) Monthly.

Articles in about 275 journals, annuals, and society publications are listed in this new Turkish index, which is arranged by subject with an author index. All titles are given in both Turkish and French, and very brief annotations are added for some entries; book reviews are included. Annual indexes by author and subject are planned. Of particular interest is the intention of the Institute to make available microfilms, translations, or abstracts of all articles included.

\section{Religion}

Dekkers, Eligius. Clavis patrum latinorum, qua in novum corpus christianorum edendum optimas quasque scriptorum recensiones a Tertulliano ad Bedam; commodo recludit Eligius Dekkers; opera usus qua praeparavit et iuvit Aemilius Gaar, Vindobonensis. Steenbrugis, In Abbatia Sancti Petri [I95I] 46Ip. (Sacris erudiri; jaarboek voor godsdienstwetenschappen, 3, I95 I)

A key to the Latin writings of the church fathers that have appeared in collections and periodicals. There are three indexes: I, Index nominum et operum; 2, Index systematicus; 3, Initia.

Kasher, Menahem M. Encyclopedia of Biblical Interpretation, a Millennial Anthology. Translated under the editorship of Rabbi Dr. Harry Freedman. N.Y., American Biblical Encyclopedia Soc., 1953- V.I- (In progress)

v.I covers Genesis, $1: 1-6: 8$.

A monumental collection of Jewish interpretations of the Bible. Includes an anthology of passages drawn from the Talmudic-Midrashic literature pertaining to each verse of the Bible, with indication of sources; a commentary containing exegetical passages from ancient and modern sources, and an appendix contain- ing four essays: Concept of time in Biblical and post-Biblical literature; The atom in Jewish sources; Creation and the theory of evolution; Creation and human brotherhood.

Miller, Madeleine S. and Miller, J. Lane. Harper's Bible Dictionary. N.Y., Harper, I952. 85Ip. il. \$7.95; Thumb indexed $\$ 8.95$.

A useful and usable one-volume alphabetically arranged encyclopedic dictionary, though not as comprehensive as Hastings (K89) nor Jacobus (K93). It treats the archaeology, geography and chronology of the Bible, including names of persons and places, ideas, Books of the Bible, phrases, objects, etc. Pronounciation is indicated for some but not all difficult or unusual words or phrases. Illustrated with photographs, line drawings and maps, Bibliographical references are sometimes but not systematically given.

\section{Reallexikon für Antike und Christentum;}

Sachwörterbuch zur Auseinandersetzung des Christentums mit der antiken Welt. In Verbindung mit Franz Joseph Dölger, Hans Lietzmann, Jan Hendrik Waszink und Leopold Wenger, hrsg. von Theodor Klauser. Stuttgart, Hiersemann, I95052. V.I-2 (incompl.) (In Progress).

Bd. I, Lfg. I-8, A-Bauen; Bd. 2, Lfg. 9-II, Bauer-Böser Blick.

Long signed articles by many scholars dealing with the relationship of the ancient world and Christianity up to the sixth century A.D.

\section{Social Sciences}

\section{Current Sociology. La sociologie contem-} poraine. [Paris] UNESCO, I953-

v.I, no. I-

This new quarterly journal will present in some issues classified bibliographies of sociological publications and in others articles in the field of sociology. In this first issue the bibliography includes publications, both books and periodical articles, that appeared between January and June 195I. The scope is international and sociology is used in. its widest sense. However, an attempt is made to avoid overlapping with other indexes in this field, such as the Population Index and Psychological 
Abstracts. A list of the periodicals used, and author and subject indexes, are included.

\section{Handwörterbuch der Sozialwissenschaften.}

Stuttgart, G. Fischer [1952- ] Fasc. I-

This new edition of the Handwörterbuch der Staatswissenschaften (4th ed. 1923-29) (L229) is now being published in fascicles, which will start at three different points of the alphabet, $\mathrm{A}, \mathrm{H}$ and $\mathrm{Re}$. The first part to appear covers Handelsrecht to Hume, David. Articles are signed and include bibliographies which give author, title, place and date of publication. There are some statistical tables and a few footnotes. Inside the front and back covers is the table of contents (in alphabetical order) giving the subject headings which appear in this or in other parts. When the set (6v.) is completed in 1955, an extra volume is planned to contain the overall table of contents, a list of all the writers, and a list of all the references cited.

\section{International Year Book and Statesmen's Who's Who, 1953- London, Burke's Peerage, Ltd., I953- annual.}

A new annual in four main parts: (I) An introductory section covering the reigning royal families of the world and information on various international organizations; (2) the states of the world, giving, for about 95 countries, constitution and government, area and population, financial and banking system, industry and commerce, communications, education, religion, etc.; (3) a diplomatic section listing the names and addresses of ambassadors and ministers of each country; (4) a biographical section giving brief biographical sketches of some 8,000 persons including statesmen and politicians, ambassadors, heads of government departments, military chiefs, great ecclesiastics and eminent lawyers, heads of the greater industries and leading bankers and merchants.

Thèses de sciences sociales: catalogue analytique international de thèses inédites de doctorate, 1940-1950. Theses in the social sciences: an international analytical catalogue of unpublished doctorate theses, I940-1950. [Paris] UNESCO [cI952] 236p. \$I.25.

Contains listings from 30 member states, and from Germany, which was not a member at the time of the survey. Titles have been translated when necessary into French or English. Listings are under broad subject, and then alphabetical by the French version of a country's name. There is an index to authors and an index to the broad subjects used.

\section{Business}

Benn, A. E. The Management Dictionary; Standardization of Definitions and Concepts of the Terminology in the Field of Personnel Management. N.Y., Exposition Pr., 1952. 375p. \$7.50.

An attempt to provide standard definitions for terms connected with personnel management; 8,624 sources from 1945 to date were searched, and a list was made of those terms on which at least five sources agreed. This list was considered by a group of experts and only those terms on which they agreed were included in the dictionary.

Encyclopedic Dictionary of Business; prepared by the Editorial Staff of PrenticeHall, Inc. N.Y., Prentice-Hall, 1952. 704p. il.

Covers terms in the many fields of business activity. Designed to provide an understanding of business operations, methods and practices, and a warning of possible legal difficulties concerning terminology.

\section{Education}

Sasnett, Martena Tenney. Educational Systems of the World: Interpretations for Use in Evaluation of Foreign Credentials. [Los Angeles] Univ. of Southern Calif. Pr., I952. 838p.

Bibliography, p.754-838.

Gives detailed information on the educational system of each country, with indications of equivalent evaluation in the U.S.

United Nations Educational, Scientific and Cultural Organization. World Handbook of Educational Organization and Statistics. Ist ed., I95I. Paris, UNESCO, 1952. 469p. \$9. 5is.6d 2.5oofr. 
"The ideal entry for each state comprises a short descriptive passage, bibliography, diagram, classification of school types and set of statistical tables." Pref. Compiled mainly from replies to questionnaires or, where these were not returned, from official printed statistics. Fifty-seven countries are covered. A useful glossary of terms gives English equivalents for foreign types of educational institutions, in five groups (pre-school, primary school, etc.).

Your Opportunity, to Help Others, to Help Yourself, 1952/1953- ; an Annual Catalog of Grants, Fellowships, Scholarships, Opportunities, Awards, Prizes, Loan Funds, Competitions, ed. and pub. by Theodora S. Jones. Milton, Mass., I952- (1952/53, paper \$3.95, cloth \$4.95.)

Arranged alphabetically, with many crossreferences from individual fellowships, prizes, etc. to the field of interest concerned. Gives names and addresses of administrative agencies, funds available, eligibility requirements, closing dates for application, etc.

\section{Linguistics}

Romera-Navarro, Miguel. Registro de lexicografía hispánica. Madrid, C.S.I.C., I951. IOI3p. (Revista de filologia española. Anejo 54.)

This is an index to some 80,000 articles or studies on individual Spanish words, listed alphabetically by the words. The references are to periodicals, books, and scholarly collections in various languages, excluding Spanish or Latin-American dictionaries and general etymological glossaries, and complete linguistic studies of individual authors. Latin-American and dialect words are included, and some Portuguese words which are closely related to the Spanish.

\section{Dictionaries}

Kurath, Hans, ed. Middle English Dictionary. Sherman M. Kuhn, assoc. ed. Ann Arbor, Mich., Univ. of Mich. Pr., I952- Pt.E, I-

This important new dictionary, a research project of the University of Michigan, is based on a vast collection of Middle English quotations, which includes all those assembled for the Oxford English Dictionary, both published and unpublished, in addition to hundreds of thousands gathered for this work. It is to be completed in ten years, in parts of 124 pages each, the whole to consist of about 8,000 pages. The bibliography and a full description of the editing plan are to appear as a separate part in 1953. The first letter to be published is $\mathrm{E}$, of which parts $\mathrm{I}-2$ (Eescheu) have so far been received; F, D, C, B and $A$ will follow, in that order, and then $\mathrm{G}-\mathrm{Z}$ in alphabetical sequence.

\section{Science}

Gaudenzi, Nerio. Guida bibliografica internazionale per il chimico. Libri e riviste. Firenze, Sansoni, 1952. 509p.

Introduction and classification scheme in Italian, French, English, and German. A classified bibliography of about 3268 books and I 25 periodicals in the field of chemistry, with indexes of periodicals, authors, subjects, and publishers. A second volume is planned to cover metallurgy.

Wilson, Edgar Bright, Jr. An Introduction to Scientific Research. Ist ed. N.Y., McGraw-Hill, I952. 388p. \$6.

Mainly concerned with statistical methods and laboratory techniques. Brief bibliographical notes at the end of each section, but no general bibliography. A useful guide for graduate students and others beginning research in the sciences.

\section{Technology}

Boone, Lalia Phipps. The Petroleum Dictionary. Norman; Univ. of Oklahoma Press., 1952. 338p. \$5.

Bibliography, p.333-8.

Gives definitions and sources of about 6,000 terms used in the oil industry. The dictionary is preceded by a general introduction ( $p \cdot 3-37$ ) to the language of the oilfield.

\section{Home Economics}

Simon, André L. Bibliotheca gastronomica, a Catalogue of Books and Documents on Gastronomy, comp. and anno- 
tated with an Introduction ... London, The Wine and Food Society, 1953. I $96 \mathrm{p}$. il. $84 \mathrm{~s}$.

"The production, taxation, distribution and consumption of food and drink, their use and abuse in all times and among all peoples."

An annotated listing of 1644 items, arranged alphabetically by author, with indexes by shorttitle and by subject.

Simon, André L. A Concise Encyclopaedia of Gastronomy. London, Collins, 1952. 827 p. 42 s.

Originally published in parts from I9391949. The sections cover (I) Sauces; (2) Vegetables; (3) Cereals; (4) Fruit; (5) Fish; (6) Meat; (7) Birds and Eggs; (8) Cheese; (9) Wine.

Includes definitions of terms and ingredients as well as recipes.

\section{Architecture and Decoration}

Hamlin, Talbot, ed. Forms and Functions of Twentieth-Century Architecture. N.Y., Columbia University Press, 1952. 4v. il. \$75. ,

"Prepared under the auspices of the School of Architecture of Columbia University."

v.I, The elements of building; v.2, The principles of composition; v.3-4, Building types.

An extremely important work, which largely supersedes Gaudet's Eléments et théorie de l'architecture (1902). Many specialists collaborated on it, and each building type is dealt with by an outstanding architect. Although there is no general bibliography, each chapter has a list of suggested additional readings; there is a general index, and also one of architectural works described or illustrated.

Gloag, John. A Short Dictionary of Furniture, Containing I764 Terms Used in Britain and America. London, Allen and Unwin, 1952. 565p. il. \$6.30.

Brief but clear definitions and descriptions, with many line-drawings. Preliminary sections cover (I) description and (2) design of furniture, and the dictionary is followed by lists of British and American furniture makers and designers and British clockmakers; bibli- ography ; tabulated periods, types of furniture, materials and craftsmen from IIOo to I950.

Emphasis mainly British.

Music

American Society of Composers, Authors and Publishers. The ASCAP Biographical Dictionary of Composers, Authors, and Publishers. Ed. by Daniel I. McNamara. 2nd ed. N.Y., Crowell, I952. 636p. \$5.

First ed., I948 (Q246)

Includes sketches of 2, I I I writers of lyrics and composers, 1400 of whom are writers of popular music, and 402 publishers of music. Arrangement as in Ist ed.

Krohn, Ernst C. comp. The History of Music; an Index to the Literature Available in a Selected Group of Musicological Publications. St. Louis, Mo., Washington Univ., I952. 463p. (Washington University Library Studies, no. 3)

An index to material on the history of music appearing in some 40 periodicals. Arrangement is by broad period divisions, further subdivided under such headings as General Studies, Composers, and the various musical forms. Indexes by authors and composers. The material was collected in card-index form by the compiler over about twenty-five years, but the periodicals covered are not confined to that period.

\section{Literature}

Brewer, Ebenezer Cobham. Brewer's Dictionary of Phrase and Fable. rev. and enl. London, Cassell, [1952]. 977p.

An entirely revised edition of this standard work. For earlier edition and annotation see $\mathrm{R}_{3} 8$. Articles have been rewritten, many shortened or omitted. New articles have been added including terms used in World War II. Both editions will be needed, as much useful material in the older edition has been dropped from the new.

Granger's Index to Poetry. 4th ed., completely rev. and enl., indexing anthologies 
published through December 31, 1950. Ed. by Raymond J. Dixon. N.Y., Columbia University Press, I953. I832p. $\$ 35$.

A completely revised edition of the standard work (for 3 rd ed. and supplement see R 159 ). This edition indexes 577 volumes of anthologies; of these 312 also appeared in the $3 \mathrm{rd}$ edition, 86 in the Supplement, and 179 are completely new.

Changes made in this edition include (I) the combining of the separate Title Index and First Line Index into one Title and First Line Index; (2) the dropping of prose selections, accounting for the disappearance of "and Recitations" from the titles; and (3) addition of a Subject Index.

The book is divided into three parts; (I) Title and first line index; (2) Author index; (3) Subject index.

A very useful addition to the reference shelf; earlier editions should be kept for the indexing of anthologies omitted from this edition.

\section{Margadant, S. W. F. Twintigduizend citaten aphorismen en spreekwoorden. 's-Gravenhage, Leopolds uitgeversmij, I952. $74 \mathrm{I} \mathrm{p}$.}

\section{Ist ed. 1935.}

Includes some 20,000 quotations in Dutch, many of them translations from other languages, for which the original is usually given. Sources include ancient and modern literatures, proverbs, maxims, etc. Arranged by topic with some cross-references. No word index.

Menéndez y Pelayo, Marcelino. Bibliografía Hispano-Latina clásica, edición preparada por Enrique Sanchez Reyes. Santander, Aldus S.A. de Artes Gráficas, I950-1952. v.r-8. (Ëdicion Nacional de las obras completas de Menéndez Pelayo dirigida por Angel Gonzalez Palencia. t.44-5 I.)

v. I-8, A Virgilio.

A bibliography listing Spanish editions of the Latin classics including: manuscripts, editions, commentaries, translations, critical works, imitations, and works showing the influence of Latin classics on Spanish literature. Sections are somewhat unequal in treatment reflecting the special interest of the compiler; some authors, e.g. Horace, Cicero, Virgil are treated at great length. Comments, extracts, etc. are given throughout. Actual bibliographical information is not always complete.

\section{Schneider, Georg. Die Schlüsselliteratur.}

Stuttgart, Hiersemann, 1951-52. v.1-2 (In progress) DM 32.

Contents: Bd. I, Das literarische Gesamtbild ; Bd. 2, Entschlüsselung deutscher Romane und Dramen.

A key to the identities of real characters and events treated in literature under fictitious names. Not all-inclusive but treats the significant works of many literatures. The first volume gives general explanations and definitions, history and discussion with indexes of authors and prototypes, the second volume is devoted to German fiction and drama and the third will deal with non-German literature.

\section{Geography}

Alexander, William McCombie. The Place-Names of Aberdeenshire. Aberdeen. Pr. for the Third Spalding Club, I952. 419p.

List all place-names in the county of Aberdeen which were in use before 1850 , current and obsolete. Local pronunciation is given.

South Africa. Place Names Committee. Amptelike plekname in die Unie en Suidwes-Afrika. (Goedgekeur tot einde 1948). Official place names in the Union and South West Africa. (Approved to end 1948). Pretoria, Govt. Printer, 1952. 376p. 25s.

A list of approved place-names showing for each correct spelling, indication of province and whether the place has a railway station, motor-bus halt, post-office, etc.

\section{History}

Diccionario de historia de España desde sus origenes hasta el fin del reinado de Al- 
fonso XIII. Madrid, Revista de occidente, [1952] $2 \mathrm{v}$.

An alphabetical dictionary of persons, events, and subjects in the history of Spain up to the end of the reign of Alfonso XIII in I93I. Articles are generally brief, though some of the more important entries cover several pages; all are signed. Bibliographical sources, not given in the text, appear in an Indice historigráfico (v.2, p. 1493-1519), which is followed by a chronology and a number of sketch-maps. Specialists were in charge of each period or field, and were assisted by a number of collaborating scholars.

\section{Elwell-Sutton, Laurence Paul. A Guide} to Iranian Area Study. Wash., Amer. Council of Learned Societies, I952. 235p. \$4.

Compiled under the auspices of the Committee on Near Eastern Studies of the American Council of Learned Societies.

Includes survey articles on the geography, population and language, social evolution, history, administration, economic structure, religion, intellectual development, literature and arts. These are followed by a Chronology, p. I IO-I6I, and a Bibliography, p.162-235.

Ettinghausen, Richard. A Selected and Annotated Bibliography of Books and Periodicals in Western Languages Dealing with the Near and Middle East: with Special Emphasis on Modern and Medieval Times. Wash., Middle East Inst., I 952. II I p. \$I.50.

Lists 1719 western-language books, and the more important periodicals, with very brief annotations. Includes titles published through Summer 195I. Selection was made by a group of scholars and the list is intended primarily for the use of colleges and libraries.

Rosenthal, Franz. History of Muslim Historiography. Leiden, Brill, I952. 558p. \$I 2 .

A comprehensive history and discussion of historical writing among the Moslem peoples.

Rössler, Hellmuth and Franz, Günther. Biographisches Wörterbuch zur deutschen Geschichte. München, Oldenbourg, 1952- Lfg. I-3, Abbe-Hessen. (In progress). DM45 the set.

$T_{0}$ be complete in about 45 signatures (8-9 to a Lfg.): parts to appear to 2-monthly intervals. Will include some 2,000 individual biographies, in all fields and from Roman times up to 1933, mainly of Germans but also of some foreigners important in the history of Germany. Brief bibliographical notes.

p. ix-xix, index by period; p. xx-xxxi, index by field or profession (subdivided by period); p. xxxii-xlviii, index by region (subdivided by period).

Westfälische Bibliographie, hrsg. von der Historischen Kommission für Westfalen in Verbindung mit dem Verein für Geschichte und Altertumskunde Westfalens. Bearb. von Alois Bömer und Hermann Degering. Münster i. Westf., Verlag Regensberg, I952- Lfg. I-4. (Veröffentlichungen der Historischen Kommission des Provinzialinstituts für Westfälische Landes- und Volkskunde. XXIV.) (In progress).

Lfg. I-4 (Bogen I-2O), p.I-320.

Classed arrangement. An extensive bibliography of Westphalian materials including periodical articles.

\section{French Parliamentary Documents (Continued from page 258)}

mentary documents are also described in an excellent though more general, article by M. Roussier entitled "Les publications officielles du Gouvernement français." 2 In English much information about parliamentary documents has been included in a detailed study by Lidderdale. ${ }^{3}$

2 Carnegie Endowment for International Peace. European Center. Les publications officielles et la documentation internationale, ed. M. Roussier, Paris, I $952, \mathrm{pp}^{2} 3 \mathrm{I}-52$.

3 D. W. S. Lidderdale, The Parliament of France. London, The Hansard Society [195I], especially pp. I I6I $22 ;$ I 74-1 92 . 